REGE

26,2

180

Received 2 November 2018 Revised 7 February 2019 Accepted 12 February 2019

\section{Development of a management support tool for stricto sensu graduate programs}

A contingency approach to project management

\author{
Ricardo Antônio Câmara \\ Tribunal Regional Federal da 3a. Região, São Paulo, Brazil, and \\ Emerson Antonio Maccari and Renato Ribeiro Nogueira Ferraz \\ Universidade Nove de Julho, Sao Paulo, Brazil
}

\begin{abstract}
Purpose - The purpose of this paper is to investigate the contribution of a project management approach to develop a tool to support the management of Brazilian stricto sensu graduate programs (SS-GP). The Adaptive approach was chosen by applying the Project Management Life Cycle (PMLC) method.

Design/methodology/approach - The study corresponds to the concept of applied research. The qualitative approach was used. The research strategy was the action research, where participants cooperate to understand their environment, identify problems and seek a solution, simultaneously producing and using the knowledge produced.

Findings - The results showed one possible way to apply a contingency project management approach to develop the tool. In addition, indicated that its application facilitated the project work, especially when finding a solution for the project's development and when dealing with the changes inherent to the uncertainties about the problem.

Research limitations/implications - The lack of more updated information and the limitation of time and resources led to the reduction of the environment scope and of the number of functionalities developed. Practical implications - To contribute to the generation of knowledge and expertise to support the management of SS-GP in activities such as providing information to the CAPES evaluation system, academic production analysis, collaborative researcher network analysis and post-graduation program monitoring and evaluation.

Originality/value - To fill a gap pointed out by several studies, that it is not possible to automatically generate input lists to be processed by ScriptSucupira tool, based on filtered criteria, comprising the entire universe of the Brazilian SS-PG. The creators of ScriptSucupira also declared to ignore the existence of an artifact similar to that. Keywords Project management, Stricto sensu graduate programs,

Contingency approaches in project management, Academic production databases,

Project Management Life Cycle
\end{abstract}

Paper type Research paper

\section{Introduction}

The acceleration of the development and use of information has initiated a significant transition process, with major implications for societies throughout the world, affecting education and other aspects of life (UNESCO, 1996). The qualification of knowledge as one of the structural axes of productive activity has made education an indispensable condition for countries to integrate favorably in the global competitiveness process (Cabral Neto, 2012).

(C) Ricardo Antônio Câmara, Emerson Antonio Maccari and Renato Ribeiro Nogueira Ferraz. Published in Revista de Gestão. Published by Emerald Publishing Limited. This article is published under the Creative Commons Attribution (CC BY 4.0) licence. Anyone may reproduce, distribute, translate and create derivative works of this article (for both commercial and non-commercial purposes), subject to full attribution to the original publication and authors. The full terms of this licence may be seen at $\mathrm{http} / / /$ creativecommons.org/licences/by/4.0/legalcode 
Higher Education Institutions (HEIs) function in this scenario as organizations oriented toward the creation, transmission and dissemination of knowledge, playing a prominent role in the processes that shape contemporary society (Bernheim \& Chaui, 2003). In Brazil, stricto sensu graduate programs (SS-GP) are noteworthy in this respect, including both academic and professional master and doctorate degree courses (Almeida, 2010; CAPES/MEC, 2010, 2017; Moritz, Pereira, Moritz, \& Maccari, 2013; Sidone, 2013).

\section{Management support tool for stricto sensu graduate}

\subsection{Context of the problem}

Since the publication of the last edition of the Law on Guidelines and Bases of Education (LDB) in 1996, Brazilian SS-GP have received a strong boost. There was a notable increase in access to higher education and in the number of graduates, resulting in a demand for further education. Many courses were created, mostly in private institutions. At the same time, the strategic value of SS-GP increased. The role of education became more valuable to the society and these programs were considered as an expression of HEI's quality (Mainardes, Miranda, \& Correia, 2011; Maccari \& Teixeira, 2014).

In this competitive environment, the appropriate use of information can reduce uncertainty and increase the chances of success in both managerial and strategic decisions (Guimarães \& Évora, 2004; Valentim, 2007). For HEIs, efficient management supported by up-to-date, reliable and available information has become necessary, to meet the quality requirements of the Coordination for the Improvement of Higher Level Personnel (CAPES), responsible for evaluating the programs, and also to face the competition, maintaining a competitive advantage as a condition for continuity (Maccari \& Teixeira, 2014; Meyer Jr, 2008; Soares, 2014).

In Brazil, the references for obtaining information on SS-GP are the government agencies, which have made two major repositories available on the internet: the CAPES portal and the Lattes Platform (LP), published by the National Council for Scientific and Technological Development (CNPq) (Guedes, 2001; Moritz et al., 2013). However, a considerable amount of information is stored in heterogeneous databases. The lack of unified access hinders research using documents and indicators of Brazilian scientific activity (Pacheco \& Kern, 2001; Silva, Maccari, \& Quoniam, 2015).

In parallel, it is known that some tools automatically extract knowledge from the LP. The computational resources of the Scriptsucupira tool, for example, have produced knowledge capable of supporting the management of SS-GP. However, nowadays it is not possible to generate input lists for automatic processing, filtering information by criteria covering the entire universe of Brazilian SS-GP (Nigro, Ferraz, Quoniam, Alves, \& Messias, 2016; Silva et al., 2015).

This scenario suggests the possibility of filling this gap by creating an automated tool, henceforth called ListaSucupira, capable of generating input lists for Scriptsucupira, making data collection more efficient, and providing information to support managers, subsidizing educational projects focused on the HEI management. Analyzing the execution of this enterprise, Silva et al. (2015) verified that there is little knowledge regarding how to integrate CAPES and LP data, as well as about the characteristics of such a tool.

Cleland and Ireland (2007) believe that project management is the mechanism that best uses available resources to develop products that represent an organizational change, such as the ListaSucupira tool. In this sense, Christopoulos (2004) highlights the failure of initiatives in the field of technology, due to the strategy of not considering project management as a critical success factor.

Within the scope of literature and practice, several traditional approaches have established standardized models for managing projects. More recent studies, however, add value to the use of techniques, tools and skills that are appropriate to each specific project, considering that adopting a contingency management approach, adapted to the 
REGE

26,2

182

environment where it is applied, could increase the chances of project's success in organizations (Hanisch \& Wald, 2012; Shenhar \& Dvir, 2010; Wysocki, 2013).

The observation of the problem from this perspective suggests that project management concepts are the right tool for conducting the development of the ListaSucupira tool. Therefore, the choice of the approach - traditional or contingent - and the managerial model would be the fundamental issue when it comes to establishing the project's strategy, increasing the possibility of success.

\subsection{The research question}

Considering what has been said, this study seeks to answer the following question:

$R Q 1$. How can project management be used to develop a tool to support the management of SS-GP?

\subsection{Objective}

The general objective of this study is to develop a project to create an automated tool to support the management of SS-GP based on data integration from the CAPES website and from the Lattes Platform.

The project's activities should follow a management approach and model specifically selected for use in the project to be developed.

To achieve its objective, the project needs to accomplish the creation of an information support structure based on data from the CAPES and LP; the development of a logical integrated data model; the construction of a functional prototype of the tool; and the validation of the work, by evaluating the process used and the developed tool.

\section{Literature review}

The theoretical pillars considered relevant for this study comprise the management of SS-GP, the knowledge regarding academic production stored in government databases and the concepts of projects and project management.

\subsection{The management of stricto sensu graduate programs}

The Brazilian graduate system has been built over the last five decades. Although it has been developed in an unfavorable context, due to the late emergence of university institutions, the application of consistent government policies allowed it to grow without losing quality (Balbachevsky, 2005; Leite, 2002; Santos, 2003).

In 1951, the CAPES was created to coordinate the improvement of the level of university professors and to avoid that the expansion of higher education caused a decline in the standards. It is now a foundation that evaluates the SS-GP, promotes the dissemination of scientific production, invests in high-level resources and promotes scientific cooperation. The CNPq, also founded in 1951, is an agency dedicated to training people and promoting research. It subsidizes scientific publications, supports researchers training and promotes international agreements and exchanges (CAPES/MEC, 2008; Moritz et al., 2013).

A university can be considered as a special type of organization that requires its own forms of planning and management (Meyer Jr, 2008). Efforts to manage SS-GP include analyses of academic production and collaborative networks, research and development programs, policy development, course setting, curriculum development, program monitoring and evaluation (Silva, Reina, Ensslin, \& Reina, 2012; Sidone, 2013; Rolim \& Amaral, 2007).

The fulfillment of the quality requirements in the CAPES evaluation is also fundamental in the management of SS-GP. The evaluation determines the entry and 
permanence of courses in the marketplace. In addition, access to research funding is linked to academic output assessments. The evaluation results provide feedback on the qualities and shortcomings of programs, and their managers seek to improve them and solve any problems that may arise, in order to maintain or improve their ranking position, which functions as a quality seal. The programs with the best evaluations are more treasured and sought after by students (Almeida, 2010; CAPES/MEC, 2014a, b; Maccari \& Teixeira, 2014).

\subsection{Academic production stored in government databases}

The development of information technology (IT) in the public sector, the citizens demand for information and the legal need for transparency in management have resulted in increasing availability of data by governmental agencies, especially at the federal level. At the end of the last century, the use of these data to develop tools for knowledge generation, analysis and decision making was among the main IT movements (Junior \& Quintella, 2005).

2.2.1 Databases of the CAPES' portal. In the CAPES evaluation process, those responsible for the SS-GP provide data related to courses in the evaluation period through a computerized system developed for this purpose. In 2014, this system was integrated with the Sucupira Platform, a technologically more advanced tool that provides information, processes and procedures in real time (Akim, Mergulhão, \& Borrás, 2013; CAPES/MEC, 2014c).

The system groups the data into 11 thematic reports used in the evaluation process and issue of indicator reports. In order to ensure transparency and disseminate knowledge regarding its evaluation process, the CAPES publishes the reports on its internet portal, making them available for online consultation and download (CAPES/MEC, 2014a, c).

Other statistical data on SS-GP are available at the Geocapes application, which displays the content of nine databases according to their geographical location, in graph or spreadsheet form. The information related to Brazil is consolidated by state and detailed by municipality. Information from abroad is aggregated by country (CAPES/ MEC, 2014d; MEC, 2008).

2.2.2 Lattes platform and lattes curricula. The LP comprises a set of computer systems developed and maintained by the $\mathrm{CNPq}$ to manage its activities to promote and to integrate information on Brazilian and foreign researchers and institutions (Guedes, 2001). Its main module is the Lattes curriculum information system, where personal and professional data, academic and technological production from institutions, professors, students and other science, technology and innovation professionals are stored (Alves, Yanasse, \& Soma, 2012).

The curricula are available in the Hyper Text Markup Language (HTML) format, constituting an important source of information. Among the LP facilities available, one can highlight its exclusive use over the internet; custom report configuration; compatibility with various text editors; identification of inconsistencies; verification of required field completion; direct access to the search group page; profile of the scientific production of the user; and identification of possible duplications (Ferraz, Quoniam, \& Maccari, 2014; Guedes, 2001).

On the other hand, difficulties are identified regarding the full use of the LP, especially in researching the production of groups, since the curricula are made available individually. Furthermore, access to registered curricula is restricted, and those who intend to undertake macro studies depend on the permission granted by the CNPq (Quoniam \& Ferraz, 2014).

2.2.3 The Scriptsucupira tool and data extraction from the Lattes Platform. Scriptsucupira is a free software tool, available for automatic information extraction and compilation concerning sets of researchers. On a webpage, it issues bibliographic, technical and artistic productions, orientations, research projects, awards and titles, collaboration graphs and
Management support tool for stricto sensu graduate 
REGE

26,2

184

geolocation maps. The reports and graphs reflect the information extracted from the processing times (Maccari, 2015; Mena-Chalco \& Junior, 2013; Nigro et al., 2016).

The system consists of six modules with specific functions. The first three, selection, pre-processing and redundancy treatment, deal with data retrieval and processing. The other three, generation of collaborative graphs, generation of research maps and report creation, are related to the outputs that the tool can produce (Nigro et al., 2016).

In the scope of SS-GP management, the agility of the tool for data collection stands out. Tracking academic output becomes simpler and more efficient. Managers analyze professors' performance according to their lines of research, identifying and correcting deficiencies in advance, to ensure good results in the CAPES' evaluation (Maccari, 2015; Nigro et al., 2016).

\subsection{Projects and project management}

The various definitions of "projects" found in the literature converge to consider projects as interdependent sets of activities: temporary, single, multifunctional and limited consuming resources' initiatives; geared toward an objective of change; undertaken to create a specific product, service or outcome (Cleland \& Ireland, 2007; Kerzner, 2011; Maximiano, 2014; PMI, 2013; Shenhar \& Dvir, 2010; Wysocki, 2013).

Expanding the concept, Shenhar (2012) and Wysocki (2013) consider that the main focus, which validates the accomplishment of the project, must lie in the creation and delivery of business value and competitive advantage, as well as in the strengthening of organizations in the marketplace.

Traditional project management approaches apply standardized practices to define team-planning, organization and control processes (Cleland \& Ireland, 2007; Williams, 2005). From this point of view, projects are essentially similar to each other, and proper application of the conventional body of knowledge is sufficient to drive them toward positive outcomes (Shenhar \& Dvir, 2010).

Contingency approaches, in turn, consider projects as different from each other, seeking to identify the characteristics, needs and success criteria applicable to their different types. They argue that the management of a project must be suitable for its content, the environment in which it is developed, and the specific characteristics of the organization in which it is executed (Carvalho \& Rabechini Jr, 2011; Fernandez \& Fernandez, 2008; Hanisch \& Wald, 2012; Wysocki, 2013).

2.3.1 The project management life cycle model. Wysocki (2013) credits part of project failures to the lack of practical and effective ways to tailor management approaches according to the types of projects conducted in the current business environment. In this context, Yassuda (2013) concludes that this diversity shows the importance of categorizing projects by means of a system that allows the identification of variables and subgroups with common management characteristics, that are generally applicable, enabling the proposition of the most appropriate management system to be implemented.

In agreement with these assumptions, Wysocki (2013) developed the Project Management Life Cycle Model (PMLC), a typology that classifies a project and recommends an approach to its management, considering the uncertainty related to the objectives and solutions as the main criteria for categorization.

In this model, objectives and solutions are quantified in two simple and direct metrics: clear or not clear, and complete or not complete. This way of analyzing the problem determines the possible scenarios for a project, placing it according to its characteristics into one of the four quadrants of the matrix shown in Figure 1.

The PMLC addresses the following types of project: traditional, where objectives and solutions are clear, in Quadrant Q1; agile, where the objectives are clear, but the solutions are not, in Quadrant Q2; extreme, where neither the objectives nor the solutions are clear, in 


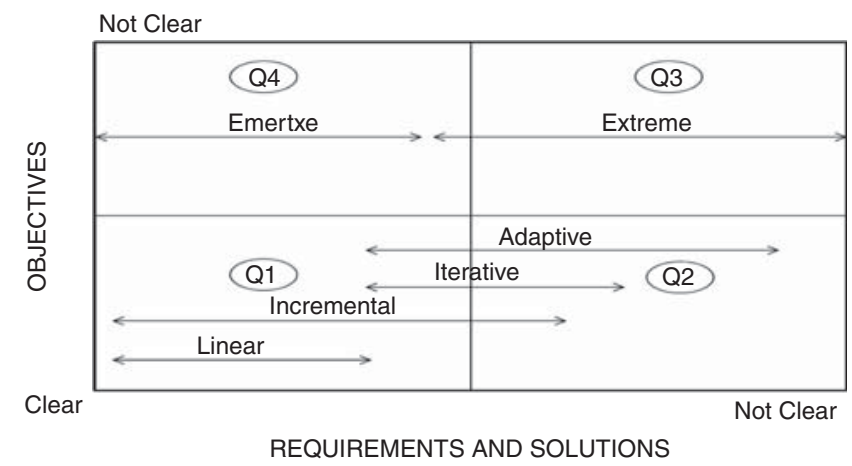

Source: Adapted from Wysocki (2013, p. 118)
Management support tool for stricto sensu graduate

185

Figure 1. Representation of the project management life cycle matrix

Quadrant Q3; and emertxe, where the solutions are clear, but the objectives are not, in Quadrant Q4 (Marinho, Sampaio, Lima, \& de Moura, 2014; Wysocki, 2013).

The model also identifies in the matrix five different life cycles related to the project types: linear and incremental for the traditional type (Q1); iterative and adaptive for the agile type (Q2); extreme (Q3) and Emertxe (Q4) for the extreme type. The latter two are considered equal, but opposite, in a way that emertxe is extreme written backwards (Marinho et al., 2014; Wysocki, 2013).

\section{Method}

As a scientific initiative, this work corresponds to the concept of applied research, according to the classification proposed by Gerhardt and Silveira (2009). It aims to investigate the reality and understand facts and phenomena in order to solve a specific problem observed in an organization. Along this process, applicable practical artifacts are prepared and new knowledge is produced (Gil, 2008; Theóphilo \& Martins, 2009).

The qualitative approach was used, which is characterized by the lack of measuring events and/or statistical analyzes; by obtaining data in direct contact with the situation; by analyzing data from different perspectives; and by using the researchers' experience and reflections to support the decision making along the process of knowledge production (Flick, 2009; Godoy, 1995).

The research strategy used herein was the action research (AR), an investigation where participants cooperate to understand their environment, identify problems and find a solution. The production and the use of knowledge occur simultaneously. The general structure of the process follows the proposal of those authors who advocate the division of AR into four main phases: exploratory, in-depth research, action and evaluation. In practice, however, the execution of the two intermediate phases takes place simultaneously (Gil, 2008; Theóphilo \& Martins, 2009; Thiollent, 2009, 2011).

The exploratory phase included the definition of the unit of analysis; the delimitation of the areas involved; the definition of the participants; the investigation of the problem using primary and secondary sources; and the proposition of a plan to achieve the goals of the study.

The in-depth research phase consisted of planning and detailing the development of most of the project work, which comprises choosing the management approach, defining data integration and specifying artifact requirements.

The action phase corresponded to the project's work itself, the activities of the four steps necessary to integrate the data, develop the logical model and construct the prototype of the tool, applying the defined management methods in the process. 
REGE

26,2

186

In the evaluation phase, the execution of the project and the results were evaluated, considering the theoretical framework that underpinned the development of the research.

\section{Presentation and analysis of the results}

The following section details the activities that were developed, taking into account the theoretical framework. Its structure considers the sequence of the logical phases, according to the previously defined AR process: exploratory, in-depth research, action and evaluation.

\subsection{Considerations on the exploratory phase}

A SS-GP in administration from a university in the city of São Paulo was chosen as the unit of analysis, due to the ease of access to information, availability of the participants and interest of the institution in the study. A single researcher was made responsible for the work. The program coordinator was given the role of main user, responsible for providing information on the program and its management needs. The researcher's access to the group that works with the Scriptsucupira tool was also guaranteed.

In the bibliographic search, there were consultations on the subject of this study, regarding books, periodicals, magazines, newspapers, websites and congress proceedings. Moreover, open interviews were conducted with the groups of researchers and representatives of the institution in question. The interviews were not recorded. Notes were taken on paper and the digital material that was received was stored on a flash drive.

The interviews conducted with the researchers of the Scriptsucupira were intended to collected information about the data available on the CAPES portal and LP. The interviewees made available computer programs for downloading the curricula ID numbers and CAPES evaluation reports, written in Phyton, a programming language. It was also confirmed that no other tools similar to ListaSucupira existed.

In the interviews conducted with the program manager, information management needs were discussed, emphasizing those related to the academic production of the professors and their collaboration networks, as well as those related to programs in the same area in other HEIs. It was also decided that the data would only consider graduation programs in Administration, Accounting and Tourism in the State of São Paulo. Only the data referring to the most recent available evaluation, conducted in 2012, would be taken into account.

The analysis led to the proposition of a tool structured in two modules: a database on SS-GP and a computerized application. The researcher also decided that a logical model of the integrated data and a functional prototype of the tool would be the artifacts produced during the study. Table I shows the work proposal.

\begin{tabular}{|c|c|c|c|}
\hline Macro stages & Stages & Activities & Deliveries \\
\hline \multirow{6}{*}{$\begin{array}{l}\text { Data } \\
\text { integration }\end{array}$} & \multirow{3}{*}{$\begin{array}{l}\text { 1. Handling information } \\
\text { from the CAPES }\end{array}$} & Manual queries to Geocapes & \multirow{2}{*}{$\begin{array}{l}\text { Consolidated list of HEIs and } \\
\text { programs }\end{array}$} \\
\hline & & Automated queries to CAPES' data & \\
\hline & & Data processing & Consolidated list of professors \\
\hline & \multirow{3}{*}{$\begin{array}{l}\text { 2. Handling information } \\
\text { from the Lattes Platform }\end{array}$} & Manual and automated queries to & Consolidated list of professors, \\
\hline & & Lattes curricula & plus data from the Lattes \\
\hline & & Data processing & Platform \\
\hline \multirow{6}{*}{$\begin{array}{l}\text { Artifacts } \\
\text { elaboration }\end{array}$} & \multirow{3}{*}{$\begin{array}{l}\text { 3. Elaboration of the logic } \\
\text { data model }\end{array}$} & Analysis of consolidated lists & \multirow[t]{3}{*}{ Logic data model } \\
\hline & & Requirements analysis & \\
\hline & & Data modeling and normalization & \\
\hline & \multirow{3}{*}{$\begin{array}{l}\text { 4. Development of the tool } \\
\text { prototype }\end{array}$} & Analysis of consolidated lists & \multirow[t]{3}{*}{ Tool prototype, functioning } \\
\hline & & Requirements analysis & \\
\hline & & Prototype programming & \\
\hline
\end{tabular}

Table I.

Stages of work execution, activities and deliveries
Source: Elaborated by the authors 
The work proposal was then submitted to the users for appreciation and approval of the exploratory phase. The proposal was accepted and the continuation of the project was authorized.

\subsection{Considerations on the in-depth research phase and on the action phase}

Following the precept of the PMLC, the process of categorizing the project and selecting the appropriate management approach began with the identification of the high-level requirements, focusing on the business objectives. The analysis of the result showed a fairly high degree of uncertainty, as the objectives were known but there was little clarity in the solution. Consequently, the project was positioned in the Q2 quadrant and the approach chosen was the Adaptive life cycle.

The main focus of the adaptive life cycle management approach is the gradual discovery of the solution. The uncertainty associated with the project is eliminated step by step. Each iteration of the project work, called a cycle, is focused on both the construction of previously defined elements and the discovery of new elements to be developed. The knowledge gained in one phase is used to plan the next one (Wysocki, 2013).

The next element to be analyzed was the impact of the risk factors and the adequacy of the adaptive model's structure to the work process defined for the project. Figure 2 shows the resulting adapted structure.

The first phase is the scope definition. The subsequent steps are the iterations, or cycles, comprising the construction of the scope elements defined in the previous phase and the discovery of new ones. The cycle phase, the only one in the adaptive model, corresponded herein to the four stages of the work plan, each one encompassing one or many complete sequences of a cycle: plan, start, monitor, control, terminate and evaluate. When stages are planned, requirements are gradually identified, detailed and recorded. The final phase corresponds to the project closure.

4.2.1 The scope definition. In the stage of detailing the scope, the two modules of the tool were specified: the database and the application. The integrated data about HEIs, programs and professors will be stored in the database. The option for constructing a specific database was due to the difficulty of recovering data from the original databases at each requested query. The proposed application is of low to medium complexity. It should provide for the generation of the entry lists, the queries and the maintenance of the data, and ensure the consistency of the selected criteria. The next step was the execution of the four work stages.

4.2.2 Stage 1 - data processing in CAPES' portal. In this stage, a spreadsheet was elaborated, containing the consolidated and validated basic data on HEIs, programs and professors. To prepare the spreadsheet, data on HEIs and programs were retrieved by means of manual consultations of the pages of the Geocapes tool (geocapes.capes.gov.br/geocapes2/). Data on the professors were retrieved by means of the automated download of the PDF files containing CAPES evaluation reports.

The efforts made to acquire and deepen knowledge in this activity in accordance with the adaptive model (Wysocki, 2013) deserve to be mentioned. The most relevant were the

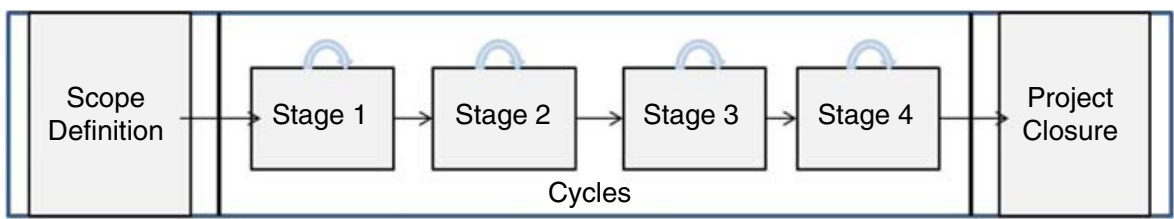

Source: Elaborated by the authors

\section{Management support tool for stricto sensu graduate}

187
Figure 2. Adaptation of the adaptive life cycle structure to the project 
REGE

26,2

188

technical efforts regarding the absorption of version 3 of the Python programming language (https://www.python.org/) and the prospection for the selection of the PDFMiner tool (www.unixuser.org/ euske/python/pdfminer/) to convert files from PDF to TXT format.

The process for the automated extraction of professors' data evolved during the course of the project work. It was necessary to consider specific characteristics of the problem, as the structure of the files did not follow a known formatting pattern. In the extraction and analysis cycles, the peculiarities of data positioning in the archives were identified. The rules that were discovered were then encoded in specific scripts and processed in automated extraction cycles.

At each cycle, new data features were discovered and the solutions to extract them were progressively incorporated into the code. As predicted in the model, at the end of each cycle the process was evaluated by comparing the results obtained with the original data.

A final automated procedure compared the quantities retrieved from the evaluation reports with those published by the CAPES. There were no divergences and the results produced in this stage were considered correct.

After the last cycle, the consolidated data on HEIs and programs, in addition to the list of 526 professors, were exported to an Excel spreadsheet. Each set of information was organized in a tab. The worksheet was considered as the final product of the stage 1 and as an evidence of the correctness of the data produced.

4.2.3 Stage 2 - data processing in Lattes Platform. In this stage, data on professors' background and education were retrieved from the LP through automated queries, supplemented by manual searches and web queries. Knowledge production was related to the process of retrieving data from HTML response pages, the refinement of search strategies, the definition of ranking criteria and the selection of similarity by checking algorithms.

The access identifiers regarding the curricula, also known as idLattes10 and idLattes16, were added to the spreadsheet as well as the curricula summaries. Each identifier corresponds to a 10 or 16-digit code, which gives access to the webpage where the researcher's curriculum is stored (Nigro et al., 2016). The results were then validated and a new spreadsheet was elaborated, containing a consolidated list of professors.

Processing and analysis cycles made it possible to discover how to retrieve the IdLattes 16 and curriculum summaries from the LP without solving the captcha, a computational resource used to hinder automated searches. However, the method discovered only proved to be applicable to pages containing links to the professor's collaboration network or their research group directories. Manual queries were submitted to the other pages in order to retrieve information.

An automated classification process was created to validate the results, checking the correspondence between the data retrieved from the LP and CAPES' portal, as well as dealing with the occurrences of homonymy. For professors' names, data from both sources were compared, using the Levenshtein Distance and Dice Coefficient algorithms to calculate the similarity degree.

Each result was punctuated and ranked. It was verified that the scores reached 72.42 percent of the maximum possible for names with single IdLattes16, and 70.65 percent for names with multiple IdLattes16. These percentages where considered sufficient to provide a good margin of safety for managers' future analyses. To increase reliability, the correspondence between names from the two sources was manually checked and it was found a success rate of 100 percent.

Based on this validation, the results were considered correct. Data were organized in two tabs of a new Excel spreadsheet, which was considered as the final product of the stage 2, serving as a record of the scoring history and evidence of data generation correctness. Thus, the data integration phase was concluded. 
4.2.4 Stage 3 - analysis and preparation of the logical data model. The prerequisites of this stage were the existence of the integrated data set and the knowledge acquired on it, which occurred in the previous stages.

The work, essentially technical, was carried out by the researcher, based on his knowledge and experience, as Flick (2009) and Thiollent (2011) consider possible in the AR.

The assumptions to accomplish the work were meeting users' requirements; facilitating implementation; facilitating maintenance; and creating a flexible model for future expansions.

Initially, the main groups of information were identified, as well as their attributes, the indication of their origin and the values they can assume. Information on professors, programs, assessments and HEI was considered. During the creation of the model, other data were identified and added to the logical data model.

The relational database, the most popular in the IT market, was the chosen data storage technology. To support this activity, the brModelo tool was used (sis4.com/brModelo/ download.aspx).

When modeling, the normalization technique was applied to the data, in order to reduce redundancy and minimize the chances of creating inconsistencies. The resulting logical data model is shown in Figure 3.

The model comprises 19 tables and 82 fields. Logical relationships and referential integrity are indicated according to the theoretical principles of the relational model. "Number," "Text" and "Boolean" are the generic data types proposed, without size specification.

4.2.5 Stage 4-construction of the tool prototype. The last stage consisted of constructing a ListaSucupira tool prototype, using the results generated during the data processing in LP. Like in the previous stage, the activities were of a technical nature, executed mostly by the researcher, based on his knowledge and experience.

In order to meet the needs agreed on by the program manager, the prototype should include three basic functionalities: allow consultations based on several criteria to form data groups; identify and retrieve data meeting the set criteria; and generate the input lists to be processed by Scriptsucupira.

The Excel spreadsheet was the container chosen for the prototype, because it is compatible with the outputs produced, supports data selection and query functionality natively and enables programming routines through Visual Basic for Apliccations (VBA) language.

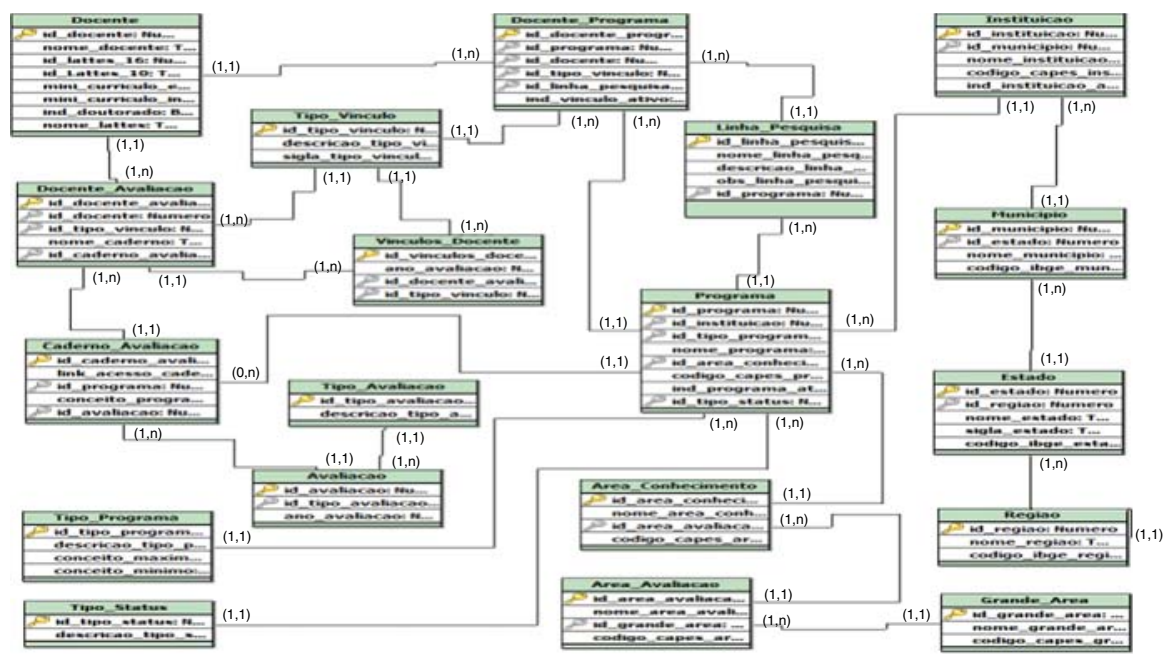

Source: Elaborated by the authors using the brModelo tool
Management support tool for stricto sensu graduate
Figure 3.

Logical data model prepared for the database 
REGE

26,2

190

The prototype consists of a spreadsheet with two tabs, the first one is used to select data, and the second one to generate input lists. In order to be used, it must be copied to any folder on a computer where Excel is installed.

To create an input list of professors using the tool, it is first necessary to select their names by using several criteria. Native Excel filters can be applied to the spreadsheet data, allowing a wide range of choices: auto filters, number filters, text filters and advanced filters. The first tab of the prototype is shown in Figure 4.

For each selected criterion, the displayed information is compatible with the data already selected so far. This feature prevents errors and ensures the integrity of data selection.

After selecting the group of professors, it is necessary to generate the lists for the Scriptsucupira from the second tab, which comprises a data display area and four buttons of possible actions, as shown in Figure 5. All the functionalities of the buttons were programmed by the researcher using the VBA language.

The "Gerar Lista" button transfers to the data area the specific rows and columns of the lines selected in the first tab. For this purpose, the display area must be empty. Therefore, all the data displayed referring to the last query performed must be deleted by pressing the "Limpar Resultados" button.

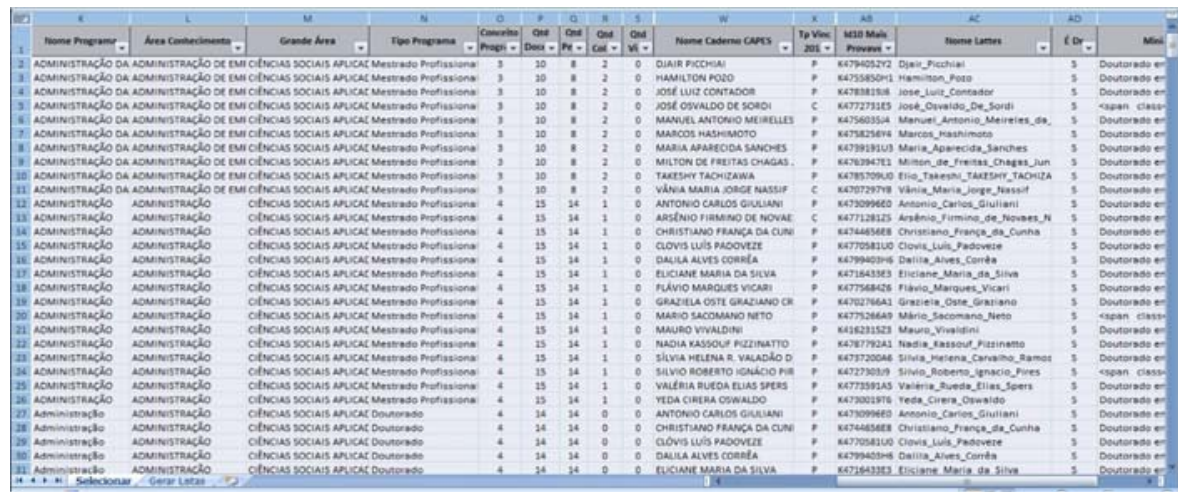

Prototype tab to select data

Source: Elaborated by the authors

Figure 5.

Prototype tab to generate input lists for the Scriptsucupira tool

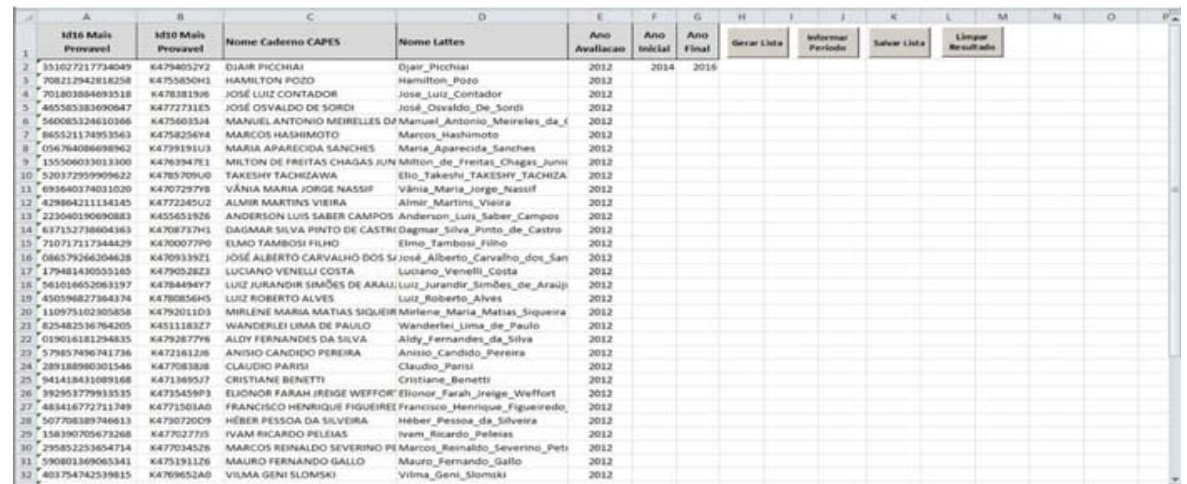

Source: Elaborated by the authors 
The "Salvar Lista" button records the data in the display area, minus the header, in a TXT file, which is stored in the same folder as the spreadsheet. Before recording, it is necessary to input the period to be considered for processing, by pressing the button "Informar Periodo." The file generated can now be submitted as an input for the Scriptsucupira tool.

The prototype's compatibility with business requirements was validated by the program manager, who presented suggestions related to the nomenclature and the visibility of the fields. These suggestions were incorporated into the final version. The delivery was approved, the implemented functionalities were validated and the stage 4 was finished.

4.2.6 Project closure. A project executed according to the adaptive model ends when the deadline or the budget is exceeded, or the project is canceled, or an acceptable solution is found. In this study, closure was caused by the latter criterion, after the acceptance of the results. That fact also closed the AR phases of in-depth research and action.

It should be noted that the adaptive model also satisfies the high-level requirements defined for the project. From this perspective, it was considered that the desired level of success was achieved, since the solution found and each artifact produced were all approved and accepted by the program manager.

\subsection{Considerations on the evaluation phase}

The adaptive model proved to be efficient. During the definition of the management approach, the project's major challenge was identified, demonstrating the benefit from that initial analysis. At the same time, the elicitation of high-level requirements avoided time-consuming analyses of poorly understood procedures and established a focus for the project work, making it possible to identify and correct deviations, at the end of each cycle.

During the execution of the project, the model was adjusted according to the needs. Successive cycles of planning, execution and evaluation proved to be efficient, especially in order to address the problems arising from uncertainties. As anticipated, applying the knowledge of one cycle in the planning of the next one led to the gradual discovery of a solution.

In the cycle closure evaluations, the needs for new knowledge and technologies were identified in advance. Flexibility in time control and scope definition facilitated the incorporation of new elements into the project, enabling the more agile and efficient management of changes and contingencies.

Finally, it is important to emphasize the knowledge acquired about Python and VBA programming languages, integration of data, queries to the LP and extraction of data from PDF files.

\section{Conclusion and final considerations}

This AR, conducted in an HEI, investigated the application of a contingency management approach in a project, executed to develop a tool to support SS-GP management. Such a tool will allow the consultation of data retrieved from the CAPES' Portal and LP, as well as the automated generation of input lists to be processed by the Scriptsucupira tool. For this purpose, the contingency Adaptive model was chosen, using Wysocki's (2013) project management life cycle method.

The application of the adaptive model precepts proved to be fundamental to find a solution for the project's development. The model's adaptability and flexibility features were useful to face the main difficulty of the project, which was the uncertainty related to the procedures and the requirements to integrate the data and build the tool prototype.

The expected success criteria were related to the business objectives to be met. In this sense, the representatives of the researched institution positively approved the artifacts resulting from the project. The production, delivery and homologation of these artifacts also determined the success in achieving the other objectives. 
REGE

26,2

Thus, we conclude that the activities developed during the study affirmatively answered the proposed research question. The results showed one of the possible ways to apply a contingency project management approach to develop ListaSucupira, a tool used to support SS-GP management. In addition, they indicated that the application of this approach facilitates such tool development, especially when dealing with the changes inherent to the uncertainties about the problem to be solved.

As for the proposed tool, it is believed that it can help to fill a gap in the analysis of academic production and other activities focused on SS-GP management, contributing to streamlining the process and minimizing the occurrence of errors. In the academic field, the tool offers potential resources to support studies based on data from the Lattes curricula.

Stretton (2011) highlights the great diversity of project application areas and the dearth of materials that summarize practices or processes in specific areas. In this sense, it is expected that the present study will contribute to the advancement in project management by presenting specificities of an educational organization in the SS-GP area. The details of the procedures, problems, errors and correctness described herein, when incorporated to the organizational knowledge, can be reused in the form of lessons learned in projects of the institution or others with a similar profile. All the documents produced during the phases of the study are available for consultation.

The main limitation of the work was the lack of more updated information. The CAPES data used in the research were related to the 2010-2012 triennium. With up-to-date information, ListaSucupira can capture data that is closer to reality, generating more consistent input lists for processing, allowing near real-time management. Furthermore, the limitation of time and resources reduced the scope of the environment and led to the development of functionalities only in prototypes and to the non-application of some artifacts and techniques of the model.

Finally, it may be observed that the limiting elements also indicate opportunities to continue this work. The natural way would be to develop an information system that fully implements the tool proposed herein in a robust computing environment and integrate a more comprehensive data set.

\section{References}

Akim, É. K., Mergulhão, R. C., \& Borrás, M. Á. A. (2013). Proposta de análise de falhas na coleta de informações para a avaliação de programas de pós-graduação baseada no FMEA. Revista Eletrônica Produção \& Engenharia, 5(1), 500-518, Available from: www.fmepro.org/ojs/index.php/rpe/article/ view $/ 8 / 6$

Almeida, M. H. (2010). A pós-graduação no Brasil: onde está e para onde poderia ir, em Plano Nacional de Pós-Graduação (PNPG) 2011-2020 Documentos Setoriais Volume II. DTI/CGD/CAPES. Available from: www.capes.gov.br/images/stories/download/PNPG_Miolo_V2.pdf

Alves, A. D., Yanasse, H. H., \& Soma, N. Y. (2012). LattesMiner: uma linguagem de domínio específico para extração automática de informações da Plataforma Lattes: Apresentado em XII Workshop de computação aplicada, São José dos Campos. Available from: www.docplayer.com.br/ 13405080-Lattesminer-uma-linguagem-de-dominio-especifico-para-extracao-automatica-deinformacoes-da-plataforma-lattes.html

Balbachevsky, E. (2005). A pós-graduação no Brasil: novos desafios para uma política bem-sucedida. Os desafios da educação no Brasil (Vol. 1, pp. 285-314). Rio de Janeiro: Nova Fronteira. Available from: www.portais.ufg.br/up/67/o/Pos-Graduacao_Brasil_2.pdf

Bernheim, C. T., \& Chaui, M. d. S. (2003). Challenges of the University in the Knowledge Society, Five Years After the World Conference on Higher Education. paper produced for the UNESCO Forum Regional Scientific Committee for Latin America and the Caribbean (UNESCO Forum Occasional Paper Series N 4). Available from: unesdoc.unesco.org/ark:/48223/pf0000134422?posInSet=1\& queryId=c1760e8c-7a3b-46df-81b8-3c1a4c948227 (accessed March 17, 2019). 
Cabral Neto, A. (2012). Mudanças contextuais e as novas regulações: repercussões no campo da política educacional. Revista Educação em Questão. 42(28), 7-40. Available from: www.periodicos.ufrn. br/educacaoemquestao/article/view/4051/3318 (accessed March 17, 2019).

CAPES/MEC (2008). CAPES - História e missão. Available from: www.capes.gov.br/historia-e-missao (accessed September 24, 2014).

Management support tool for stricto sensu graduate

CAPES/MEC (2010). Plano Nacional de Pós-Graduação (PNPG) 2011-2020 Volume I. DTI/CGD/CAPES. Available from: www.capes.gov.br/images/stories/download/Livros-PNPG-Volume-I-Mont.pdf (accessed March 17, 2019).

CAPES/MEC (2014a). CAPES - Sobre a Avaliação. Available from: www.capes.gov.br/avaliacao/sobrea-avaliacao (accessed February 21, 2015).

CAPES/MEC (2014b). CAPES - Entrada no SNPG: propostas de cursos novos. Available from: www.capes.gov.br/avaliacao/entrada-no-snpg-propostas (accessed April 24, 2015).

CAPES/MEC (2014c). Coleta de Dados - Conceitos e orientações - Versão 1.5. Available from: www. sucupira.capes.gov.br/sucupira/public/docs/manual_coleta.pdf (accessed March 17, 2019).

CAPES/MEC (2014d). GEOCAPES - Sistema de Informações Georreferenciadas I CAPES. Available from: www.capes.gov.br/component/content/article/91-conteudo-estatico/avaliacao-capes/6886-geocapes (accessed February 22, 2015).

CAPES/MEC (2017). MEC institui modalidade de doutorado profissional. Available from: www.capes.gov.br/sala-de-imprensa/noticias/8328-portaria-institui-doutorado-profissional (accessed March 17, 2017).

Carvalho, M. M. d., \& Rabechini, R. Jr (2011). Fundamentos em Gestão de Projetos: Construindo Competências para Gerenciar Projetos (3rd ed.). São Paulo: Atlas.

Christopoulos, T. P. (2004). Importância da estratégia na gestão de projetos de TI. Procceedings of the Congresso Anual de Tecnologia da Informação (Vol. 4, pp. 1-15). São Paulo: Fapesp.

Cleland, D., \& Ireland, L. (2007). Project Management: Strategic Design and Implementation (5th ed.). McGraw Hill Professional.

Fernandez, D. J., \& Fernandez, J. D. (2008). Agile project management-agilism versus traditional approaches. Journal of Computer Information Systems, 49(2), 10-17.

Ferraz, R. R. N., Quoniam, L. M., \& Maccari, E. A. (2014). A utilização da ferramenta Scriptlattes para extração e disponibilização on-line da produção acadêmica de um programa de stricto sensu em Administração. Revista Brasileira de Pós-Graduação, 11(24), 361-389.

Flick, U. (2009). An Introduction to Qualitative Research (4th ed.). London: SAGE.

Gerhardt, T. E., \& Silveira, D. T. (2009). Métodos de pesquisa (1st ed.). Porto Alegre: Plageder.

Gil, A. C. (2008). Como elaborar projetos de pesquisa (4th ed.). São Paulo: Atlas.

Godoy, A. S. (1995). Introdução à pesquisa qualitativa e suas possibilidades. Revista de administração de empresas, 35(2), 57-63.

Guedes, C. A. (2001). Currículo Lattes perguntas e respostas. Available from: www.pucrs.campus2.br/ manuais/dicas_lattes.pdf (accessed September 24, 2014).

Guimarães, E. M. P., \& Évora, Y. D. M. (2004). Sistema de informação: instrumento para tomada de decisão no exercício da gerência. Ciência da Informação, Brasilia, 33(1), 72-80.

Hanisch, B., \& Wald, A. (2012). A bibliometric view on the use of contingency theory in project management research. Project Management Journal, 43(3), 4-23.

Junior, J. S. S., \& Quintella, R. H. (2005). Descoberta de conhecimento em bases de dados públicas: uma proposta de estruturação metodológica. Revista de Administração Pública, 39(5), 1077-1107.

Kerzner, H. (2011). Gerenciamento de projetos - uma abordagem: sistêmica para planejamento, programação e controle (10th ed.). São Paulo: Edgard Blucher.

Leite, D. (2002). Sistemas de avaliação das instituições de ensino superior no Brasil. In Maria Susana Arrosa Soares (Eds.), A educação superior no Brasil (pp. 39-112). Porto Alegre: IESALC/UNESCO. 
REGE

26,2

Maccari, E. A. (2015). Gestão de pós-graduação por meio da ferramenta computacional scriptlattes. São Paulo: USP.

Maccari, E. A., \& Teixeira, G. d. S. (2014). Estratégia e planejamento de projeto para acompanhamento de alunos egressos de programas de pós-graduação stricto sensu. Revista de Administração da UFSM, 7(1), 101-116.

Mainardes, E. W., Miranda, C. S., \& Correia, C. H. (2011). A gestão estratégica de instituições de ensino superior: um estudo multicaso. Contextus-Revista Contemporânea de Economia e Gestão, 9(1), 19-32.

Marinho, M., Sampaio, S., Lima, T., \& de Moura, H. (2014). A guide to deal with uncertainties in software project management. International Journal of Computer Science \& Information Technology, 6(5), 1-20.

Maximiano, A. C. A. (2014). Administração de projetos: como transformar idéias em resultados (5th ed.). São Paulo: Atlas.

MEC (2008). CAPES lança aplicativo gráfico para consulta única de dados. Available from: portal.mec.gov.br/busca-geral/225-noticias/sistemas-1375504326/14059-capes-lanca-aplicativografico-para-consulta-unica-de-dados (accessed March 17, 2019).

Mena-Chalco, J. P., \& Junior, R. M. C. (2013). Prospecção de dados acadêmicos de currículos Lattes através de ScriptLattes. In Maria Cristina Piumbato Innocentini Hayashi e Jacqueline Leta (Eds.), Capítulo do livro Bibliometria e Cientometria: reflexões teóricas e interfaces (pp. 109-128). São Carlos: Pedro \& João Editores.

Meyer, V. Jr (2008). Planejamento universitário: ato racional, político ou simbólico-um estudo de universidades brasileiras. Revista Alcance, 12(3), 373-390.

Moritz, G. d. O., Pereira, M. F., Moritz, M. O., \& Maccari, E. A. (2013). A Pós-Graduação brasileira: evolução e principais desafios no ambiente de cenários prospectivos. Future Studies Research Journal: Trends and Strategies, 5(2), 3-34.

Nigro, C. A., Ferraz, R. R. N., Quoniam, L., Alves, W. A. L., \& Messias, L. R. R. (2015). Prestação de contas anual e quadrienal à Capes por um programa de Pós-Graduação stricto sensu em Engenharia de Produção: utilização da ferramenta computacional Scriptlattes-Scriptsucupira. Revista PRISMA, 29(1), 3-26. Available from: ojs.letras.up.pt/index.php/prismacom/article/view/1828/1664

Pacheco, R. C. d. S., \& Kern, V. M. (2001). Uma ontologia comum para a integração de bases de informações e conhecimento sobre ciência e tecnologia. Ciência da Informação, 30(3), 56-63.

PMI (2013). Um guia do conhecimento em gerenciamento de projectos (Guia PMBOK®) Quinta Edição (5a Edição) Newtown Square, PA: Project Management Institute.

Quoniam, L., \& Ferraz, R. R. N. (2014). Extração e disponibilização on-line de indicadores de desempenho e prospecção dos resultados das pesquisas em dengue realizadas pela comunidade científica brasileira por meio da utilização da ferramenta computacional Scriptlattes. Presented in XXXVIII Encontro da ANPAD, September. Rio de Janeiro: ANPAD.

Rolim, E. G., \& Amaral, L. H. (2007). A gestão da produção acadêmico-científica nas instituições de ensino superior: a experiência da Faculdade ce Ciências Médicas da Santa Casa de São Paulo. Arq Med Hosp Fac Cienc Med Santa Casa, 52(1), 3-7.

Santos, C. (2003). Tradições e contradições da pós-graduação no Brasil. Educação e Sociedade, 24(83), $627-641$.

Shenhar, A. J. (2012). What is strategic project leadership?. Presented at PMI $®$ Global Congress. October 2012-North America, Vancouver, British Columbia, Canada. Newtown Square, PA: Project Management Institute.

Shenhar, A. J., \& Dvir, D. (2010). Reinventando gerenciamento de projetos. A Abordagem Diamante ao crescimento e inovação bem-sucedidos (1st ed.). São Paulo: M. Books do Brasil Editora Ltda.

Sidone, O. J. G. (2013). Análise espacial da produção e das redes de colaboração científica no Brasil: 1990-2010. São Paulo: Universidade de São Paulo. 
Silva, H. A. S. d., Reina, D. R. M., Ensslin, S. R., \& Reina, D. (2012). Programas de pós-graduação em contabilidade: análise da produção científica e redes de colaboração. Revista de Contabilidade e Organizações, 6(14), 145-162.

Silva, R., Maccari, E., \& Quoniam, L. (2015). Uma ferramenta para apoiar a seleção de dados no processo de descoberta de conhecimento em bancos de dados de produção acadêmica. Revista Gestão \& Tecnologia, 15(1), 298-318.

Soares, L. H. (2014). Gestão de instituições de ensino: o ensino superior privado e os novos parâmetros de perenidade. Universitas: Gestão e TI, 3(2), 79-87.

Stretton, A. (2011). Notes on project/program typologies. PM World Today. Vol XIII Issue II Fevereiro de 2011, Available from: docslide.net/documents/c102-notes-on-project-programtypologies.html (accessed March 17, 2019).

Theóphilo, C. R., \& Martins, G. A. (2009). Metodologia da investigação cientifica para ciências sociais aplicadas (2nd ed.). São Paulo: Atlas.

Thiollent (2009). Pesquisa-ação nas organizações (2nd ed.). São Paulo: Atlas.

Thiollent (2011). Metodologia da pesquisa-ação (18th ed.). São Paulo: Cortez.

UNESCO (1996). UNESCO and an information society for all, France: UNESCO.

Valentim, M. L. P. (2007). A informação em organizações complexas - 1. Available from: www.ofaj.com.br/colunas_conteudo.php?cod=299 (accessed March 17, 2019).

Williams, T. (2005). Assessing and moving on from the dominant project management discourse in the light of project overruns. Engineering Management, IEEE Transactions on, 52(4), 497-508.

Wysocki, R. K. (2013). Effective Project Management: Traditional, Agile, Extreme (7th ed.). Indianapolis: John Wiley \& Sons.

Yassuda, I. d. S. (2013). Artefatos de categorização de projetos espaciais e seleção de metodologias de gestão (Doctoral Dissertation). INPE, São José dos Campos.

\section{Corresponding author}

Ricardo Antônio Câmara can be contacted at: rcamara62@gmail.com

Associate Editor: Adriana Marotti de Mello

For instructions on how to order reprints of this article, please visit our website: 